\title{
The Effectiveness of the Amount of Polymethylmethacrylate Used in the Treatment of Lumbar Osteoporotic Compression Fractures
}

\section{Lomber Osteoporotik Kompresyon Kırığının Tedavisinde Polimetilmetakrilat Miktarının Etkinliği}

\author{
Mehmet Onur Yuksel ${ }^{1} \oplus$, Serdar Cevik ${ }^{2,3} \oplus$, Baris $\operatorname{Erdogan}^{4} \oplus$, Salim Katar ${ }^{5} \oplus$, Tamer Tunckale ${ }^{6} \odot$ \\ Tezcan Calıskan $^{6 \oplus}$, Sevket Ervan ${ }^{7 \odot}$
}

${ }^{1}$ Department of Neurosurgery, Medipol University, School of Medicine Faculty, Istanbul, Turkey

${ }^{2}$ Department of Neurosurgery, Memorial Şişli Hospital, Istanbul, Turkey

${ }^{3}$ School of Healthy Sciences, Gelisim University, Istanbul, Turkey

${ }^{4}$ Department of Neurosurgery, Şanlıurfa Training and Research Hospital, Şanlıurfa, Turkey

${ }^{5}$ Department of Neurosurgery, Balıkesir University, School of Medicine, Turkey

${ }^{6}$ Department of Neurosurgery, Namık Kemal University, School of Medicine, Tekirdağ, Turkey

${ }^{7}$ Department of Neurosurgery, Haseki Training and Research Hospital, İstanbul, Turkey

Received: 21.05.2020 / Accepted: 27.10.2020 / Published Online: 29.12.2020

Cite as: Yuksel MO, Cevik S, Erdogan B, Katar S, Tunckale T, Caliskan T, Ervan S. The effectiveness of the amount of polymethylmethacrylate used in the treatment of lumbar osteoporotic compression fractures. Med J Bakirkoy 2020;16(4):330-5.

\section{ABSTRACT}

Objective: We aimed to investigate the effectiveness of the amount of polymethylmethacrylate used in pain control and maintenance of long-term vertebra corpus height in patients undergoing percutaneous vertebroplasty due to osteoporotic compression fracture of the lumbar vertebra.

Method: A total of 60 patients who underwent unilateral percutaneous vertebroplasty between 2014 and 2019 due to osteoporotic compression fracture of the lumbar vertebrae were included in the study. Patients who received $5 \mathrm{ml}$ and $3 \mathrm{ml}$ cement injection were retrospectively analyzed. Of patients, postoperative visual analogue scale (VAS) score and anterior vertebral height of the patients at 1st-year control were evaluated.

Results: In the postoperative period, the mean visual analogue scale score was $2.3 \pm 0.46$ in the $5 \mathrm{ml}$ injected group and $2.2 \pm 0.4$ in the $3 \mathrm{ml}$ injected group ( $p 5 \mathrm{ml}=0.001, \mathrm{p3} \mathrm{ml}=0.001$ ). There was a statistically significant decline in pain control in both groups. The mean anterior vertebral height loss (AVHL) in the $5 \mathrm{ml}$ injected group was $31.5 \pm 0.40 \%$, and $32.6 \pm 0.47 \%$ in the $3 \mathrm{ml}$ injected group $(p 5 \mathrm{ml}=0.820, p 3 \mathrm{ml}=$ 0.870). There was no statistically significant alteration in both groups.

Conclusion: Our results indicate that the $3 \mathrm{ml}$ polymethylmethacrylate injection during the percutaneous vertebroplasty procedure provides adequate pain control and stabilization in patients with lumbar vertebral osteoporotic fracture. Therefore we think that small amount of polymethylmethacrylate $(3 \mathrm{ml})$ is sufficient to avoid undesirable complications in this patient group.

Keywords: Compression fractures, osteoporotic fractures, pain, polymethyl methacrylate, spinal fractures, vertebroplasty, visual analog scale Öz

Amaç: Lomber vertebra osteoporotik kompresyon kırı̆ıı nedeniyle perkutan vertebroplasti yapılan hastalarda, kullanılan polimetilmetokrilat miktarının ağrı kontrolünde ve uzun dönem vertebra korpus yüksekliğinin korunmasındaki etkinliğini araştırmayı amaçladık.

Yöntem: 2014 ve 2019 yılları arasında lomber vertebranın osteoporotik kompresyon kırığı nedeniyle uniletaral perkütan vertebroplasti işlemi uyguladığımız toplam 60 hasta çalışmaya dahil edilmiştir. $5 \mathrm{ml}$ ve $3 \mathrm{ml}$ sement enjeksiyonu yapılan hastalar retrospektif olarak incelenmiştir. Hastaların postoperatif VAS skorları ve 1. yıl kontrol anterior vertebra yükseklikleri değerlendirilmiştir.

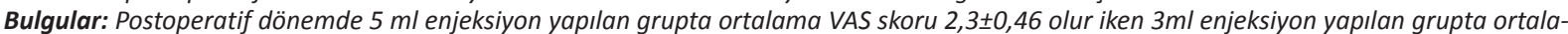
ma VAS skoru 2,2 $\pm 0,4$ idi. (p5 $\mathrm{ml}=0,001$, p3 $\mathrm{ml}=0,001$ ) Her iki grupta ağrı kontrolünde istatiksel olarak anlamlı bir gerileme tespit edildi.

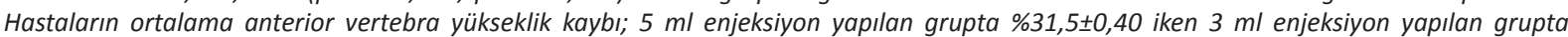
$\% 32,6 \pm 0,47$ ( $p 5 \mathrm{ml}=0,820, p 3 \mathrm{ml}=0,870)$ idi. Her iki grupta da istatiksel olarak anlamlı değişim saptanmadı.

Sonuç: Sonuçlarımız lomber osteoporotik vertebra fraktürü hastalarında perkütan vertebroplasti işlemi sırasında $3 \mathrm{ml}$ polimetilmetokrilat enjeksiyonunun yeterli ağrı kontrolü ve stabilizasyonu sağladığnı göstermektedir. Bu nedenle bu hasta grubunda gereksiz komplikasyonlardan kaçınmak için daha az miktarda (3 ml) polimetilmetokrilat kullanımının yeterli olduğunu düşünmekteyiz.

Anahtar kelimeler: Compresyon kırıkları, osteoporotik kırıklar, ağrı, polimetilmetakrilat, spinal kırıklar, vertebroplasti, vizüel analog skalası

\begin{tabular}{|c|c|c|c|}
\hline $\begin{array}{l}\text { Corresponding Author: } \\
\text { dr.onur_yksl@hotmail.com }\end{array}$ & $\begin{array}{r}\text { M.O. Yuksel 0000-0003-0922-4249 } \\
\text { S. Cevik 0000-0002-2733-4233 } \\
\text { B. Erdogan 0000-0003-4946-0748 }\end{array}$ & $\begin{array}{r}\text { S. Katar 0000-0002-8311-1122 } \\
\text { T. Tunckale 0000-0002-4534-0864 } \\
\text { T. Caliskan 0000-0001-7735-0584 }\end{array}$ & S. Ervan $0000-0003-1041-252 X$ \\
\hline
\end{tabular}

(c) Telif hakkı Sağık Bilimleri Üniversitesi Bakırköy Dr. Sadi Konuk Eğitim ve Araştırma Hastanesi'ne aittir. Logos Tıp Yayıncılık tarafindan yayınlanmaktadır. Bu dergide yayınlanan bütün makaleler Creative Commons Atf-GayriTicari 4.0 Uluslararası Lisansı ile lisanslanmıştı.

(c) Copyright Health Sciences University Bakırköy Sadi Konuk Training and Research Hospital. This journal published by Logos Medical Publishing.

Licenced by Creative Commons Attribution-NonCommercial 4.0 International (CC BY) 


\section{INTRODUCTION}

Pathological vertebral fractures are most commonly seen due to osteoporosis, which leads to bone mineral loss, but can also be seen due to tumor infiltration. Vertebral compression fractures can cause severe pain that restricts the daily activity of the patients. Analgesic treatment, physical therapy, and corset usage are generally unresponsive to the relief of pain seen in patients (1).

As a result of the vertebroplasty procedures performed in vertebral compression fractures, the resolution of the complaints of patients' pain is quite satisfactory. In the series of 100 patients, McGraw and colleagues stated that $97 \%$ of the patients had significantly reduced pain in the first 24 hours ${ }^{(2)}$.

Percutaneous vertebroplasty (PV) is a very powerful method to strengthen the vertebra with polymethylmethacrylate in pathological vertebral compression fractures caused by osteoporosis, tumor or trauma ${ }^{(3)}$. It was first applied in 1987 by Galibert and Deromond in France ${ }^{(4)}$. Percutaneous vertebroplasty can be achieved unilaterally or bilaterally. Still, no significant difference was found between them ${ }^{(5)}$. In the unilateral procedures, the polymethylmethacrylate should cross the midline and vertical axis of the vertebral corpus ${ }^{(6)}$. If the polymethylmethacrylate given remains on one side of the vertebral corpus and does not pass to the other side, it causes curvature of the spine in the future ${ }^{(7)}$.

The most important point for the efficacy of PV is that the polymethylmethacrylate should be injected at an amount sufficient to achieve enough stabilization and pain control. It is reported in the literature that 3-5 ml of cement injection is sufficient in the lumbar and thoracic vertebrae region ${ }^{(8-12)}$. Therewithal, the most common complication during vertebroplasty is polymethylmethacrylate leakage into the spinal canal or neural foramen. In the series of McKiernan et al., this rate of leakege was 15 percent ${ }^{(13)}$. Therefore, it is necessary to avoid over-injection of polymethylmethacrylate in order to ensure the effectiveness of vertebroplasty and to avoid possible complications.

In this study, we investigated the patients who underwent percutaneous vertebroplasty for osteoporotic compression fractures of the lumbar spine. We evaluated the productiveness of the amount of polymethyl- methacrylate injected on radiological findings and pain control in the postoperative period and long-term follow-up.

\section{MATERIAL and METHODS}

Sixty patients, who presented with low back pain between 2014 and 2019 and had a single-level osteoporotic vertebral compression fracture in the lumbar vertebrae detected during magnetic resonance imaging (MRI) and computed tomography (CT) tests, were included in the study. All patients Bone mineral densities (BMDs) of all patients were measured by dual X-ray absorptiometry (DXA). Patients' T-scores were between-2.5 standard deviation (SD) and -3.2 SD. Patient whose preoperative imaging studies, did not reveal bone fragments causing canal occupation, those without neurological deficits detected in neurological examinations and patients whose pain control cannot be achieved despite conservative treatment were included in the study.

Under general anesthesia, and scopy, the patients with compression fractures lying in the prone position, received percutaneous injections of polymethylmethacrylate using special needles inserted unilaterally into the vertebral corpus through the midline of the vertebral corpus, which were advanced up to anterior $1 / 3$ (Ntcem. Spine, Meta Biomed Co., Ltd Osongsaengmyeong, Korea) w (Figure 1).

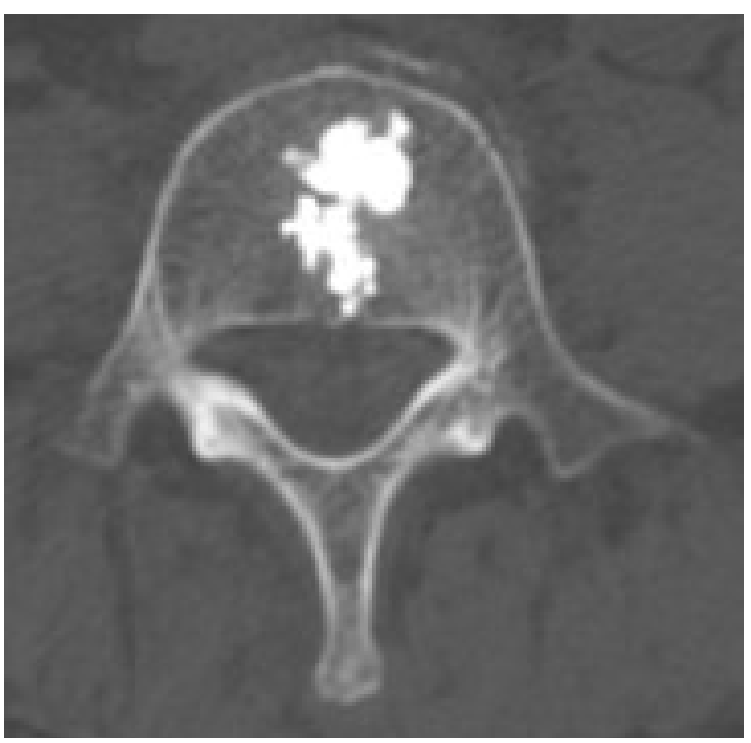

Figure 1. Axial plan CT scan. $3 \mathrm{ml}$ polymethylmethacrylate reached up to middle and anterior $1 / 3$ vertebrae. 
Five $\mathrm{ml}$ and $3 \mathrm{ml}$ of polymethylmethacrylate were injected into the vertebrae of the patients consecutively. The patients were placed in the supine position for at least 6 hours after the procedure. All patients underwent lumbar $\mathrm{CT}$ in the postoperative period and at 1st-year follow-up (Figure 2).

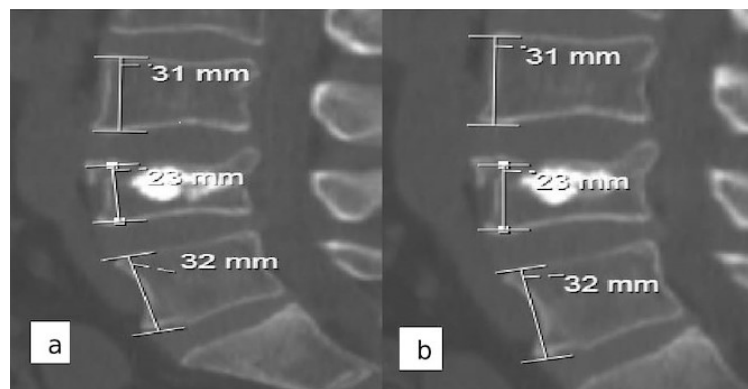

Figure 2. Sagittal plan CT scan of the patient undergoing $3 \mathrm{ml}$ of polymethylmethacrylate;

a) Post-operative 1st day b) 1st-year follow-up

The pain severity of the patients was evaluated using the VAS scores ranging between 0 , and 10 points. The height of the vertebrae in the postoperative and 1styear follow-up was measured using the Picture Archiving and Communication System. The AVHL percentage was calculated by dividing the height of the anterior wall of the fractured vertebra by the average of the anterior wall heights of the adjacent lower and upper vertebrae (Figure 3).

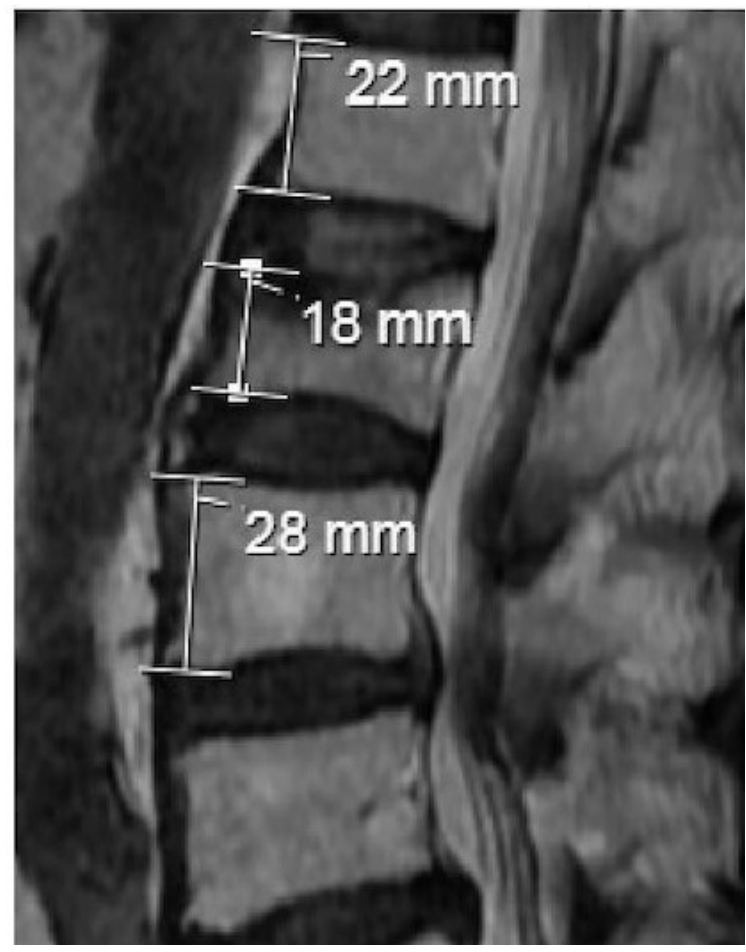

Figure 3. 2nd Lumbar vertebrae with $28 \%$ height loss.
This study was performed with clinical data collected from patient files collected retrospectively. This study was approved by the Medical Ethics Committee of Tekirdag Namık Kemal University (2019.229.12.04). All procedures performed in studies involving human participants were conducted under the ethical standards of the institutional and/or national research committee and the Helsinki Declaration of 1964 and subsequent amendments or comparable ethical standards. All permissions were obtained to access the data used in our study. Written informed consent was obtained from all patients.

Descriptive statistics were used to describe continuous variables (mean, standard deviation, minimum, and maximum). The student t-test was used to evaluate VAS value and AVHL among the groups.

\section{RESULTS}

Data were analyzed using SPSS ver. 20.0 (SPSS Inc., Chicago, IL, USA). Paired t-test was used to determine the significance of intergroup differences in preoperative and postoperative $p$ values presented as mean and standard deviation. Mann-Whitney $\mathrm{U}$-test was used to determine the significance of differences between groups presented as median with maximum and minimum values. A $p<0.05$ was considered statistically significant.

Sixty patients with lumbar spine fractures due to osteoporosis were included in the study. 45 patients were female and 15 were male. The mean age of the patients was 67.6 years (SD 3.34, range 61-76). The demographic data of the patients according to subgroups are shown in (Table 1 ).

Table 1. It showes demographic characteristics of participants.

\begin{tabular}{|l|l|l|l|}
\hline & $\mathbf{3} \mathbf{~ m l}$ & $\mathbf{5 ~} \mathbf{~ l}$ & $\mathbf{p}$ \\
\hline Age (years) & $67.2 \pm 3.09$ & $67.9 \pm 3.59$ & $0.444^{*}$ \\
\hline Weight $(\mathrm{kg})$ & $69.4 \pm 7.29$ & $71.8 \pm 9.45$ & $0.275^{*}$ \\
\hline Height $(\mathrm{cm})$ & $165.6 \pm 6.3$ & $164.8 \pm 4.78$ & $0.597^{*}$ \\
\hline BMI $\left(\mathrm{kg} / \mathrm{m}^{2}\right)+$ & $25.3 \pm 2.16$ & $24.7 \pm 2.32$ & $0.338^{*}$ \\
\hline Female/Male & $\begin{array}{l}23(77 \%) / 7 \\
(23 \%)\end{array}$ & $\begin{array}{l}22(73 \%) / 8 \\
(27 \%)\end{array}$ & \\
\hline
\end{tabular}

†BMI:Body Mass Index 
The mean VAS scores of the patients who received $5 \mathrm{ml}$ and $3 \mathrm{ml}$ polymethylmethacrylate injections during vertebroplasty were calculated as $7.2 \pm 0.4$ and $7.6 \pm 0.56$, respectively $(p=0.002)$. The mean VAS score was $2.3 \pm 0.46$ in the $5 \mathrm{ml}$ injected group one day after the procedure and $2.2 \pm 0.4$ in the $3 \mathrm{ml}$ injected group ( $\mathrm{p} 5 \mathrm{ml}=0.001, \mathrm{p} 3 \mathrm{ml}=0.001)$. A statistically significant decline in pain control was detected in both groups. Early postoperative and 1st year postoperative VAS results were similar in both groups. (Table 2)

Table 2. It showes comparison of preopertive and postoperative patients' VAS. A statistically significant decline in pain control was detected in both groups.

\begin{tabular}{|l|l|l|l|}
\hline & $\mathbf{3 ~} \mathbf{~ L}$ & $\mathbf{5 ~ m L}$ & $\mathbf{p}$ \\
\hline Pre-op VAS $^{\ddagger}$ & $7.6 \pm 5.56$ & $7.2 \pm 0.4$ & 0.002 \\
\hline Post-op VAS $^{\S}$ & $2.2 \pm 0.4$ & $2.3 \pm 0.46$ & 0.379 \\
\hline P & 0.001 & 0.001 & \\
\hline
\end{tabular}

${ }^{\ddagger}$ Pre-op VAS: Preoperative visual analogue scale.

$\$$ Post-op VAS: Postoperative visual analogue scale.

The mean AVHLs of the patients who received $5 \mathrm{ml}$ and $3 \mathrm{ml}$ polymethylmethacrylate injections during vertebroplasty procedure was $31.7 \pm 4.66 \%$ and $32.8 \pm 4.9 \%$, respectively $(p=0.377)$. At 1 st-year followup, the mean vertebral height loss in the $5 \mathrm{ml}$ injected group was $31.5 \pm 0.40 \%$ and $32.6 \pm 0.47 \%$ in the $3 \mathrm{ml}$ injected group $(\mathrm{p} 5 \mathrm{ml}=0.820, \mathrm{p} 3 \mathrm{ml}=0.870)$. In both groups, no statistically significant change was observed in vertebral height loss at 1st-year follow-up (Table 3).

Table 3. It showes comparison of preoperative and 1 st-year follow-up patients' AVHL values. In both groups, no statistically significant change was observed in AVHL at 1st-year follow-up.

\begin{tabular}{|l|l|l|l|}
\hline & $\mathbf{3} \mathbf{~ m L}$ & $\mathbf{5 ~} \mathbf{~ L}$ & $\mathbf{P}$ \\
\hline Pre-op AVHL " & $32.8 \pm 4.91 \%$ & $31.7 \pm 4.66 \%$ & 0.397 \\
\hline Follow-up AVHL " & $32.6 \pm 4.57 \%$ & $31.5 \pm 4.4 \%$ & \\
\hline P & 0.870 & 0.820 & \\
\hline
\end{tabular}

II Pre-op AVHL: Preoperative anterior vertebra height loss. "AVHL: Anterior vertebra height loss.

Mean AVHL measurements according to vertebral levels are shown in Table 4.

While no complication was observed in the $3 \mathrm{ml}$ injected group, it was found that in 3 patients who were treated with $5 \mathrm{ml}$ polymethylmethacrylate, cement leaked into the disc space, anterior part of the vertebral corpus, and into the spinal canal.
Table 4. Fracture levels of patients and the amount of collapse

\begin{tabular}{|c|c|c|c|c|c|}
\hline & & \multicolumn{2}{|c|}{ preoperative AVHL } & \multicolumn{2}{|c|}{$\begin{array}{c}\text { 1-years follow up } \\
\text { AVHL }\end{array}$} \\
\hline & & $3 \mathrm{ml}$ & $5 \mathrm{ml}$ & $3 \mathrm{ml}$ & $5 \mathrm{ml}$ \\
\hline \multirow[t]{2}{*}{ L1 (n=19) } & $n$ & 9 & 10 & 9 & 10 \\
\hline & $\begin{array}{l}\text { mean } \\
\text { AHVL }\end{array}$ & $34.3 \%$ & $29.9 \%$ & $34.1 \%$ & $29.6 \%$ \\
\hline \multirow[t]{2}{*}{ L2 ( $n=17)$} & $n$ & 10 & 7 & 10 & 7 \\
\hline & $\begin{array}{l}\text { mean } \\
\text { AHVL }\end{array}$ & $32.6 \%$ & $33.3 \%$ & $32.5 \%$ & $33.2 \%$ \\
\hline \multirow[t]{2}{*}{ L3 $(n=12)$} & $\mathrm{n}$ & 4 & 8 & 4 & 8 \\
\hline & $\begin{array}{l}\text { mean } \\
\text { AHVL }\end{array}$ & $32 \%$ & $31.4 \%$ & $32 \%$ & $31.5 \%$ \\
\hline \multirow[t]{2}{*}{$L 4(n=8)$} & $\mathrm{n}$ & 4 & 4 & 4 & 4 \\
\hline & $\begin{array}{l}\text { mean } \\
\text { AHVL }\end{array}$ & $33.3 \%$ & $31.8 \%$ & $32.5 \%$ & $30.8 \%$ \\
\hline \multirow[t]{2}{*}{ L5 $(n=4)$} & $\mathrm{n}$ & 3 & 1 & 3 & 1 \\
\hline & & $29.7 \%$ & $42 \%$ & $29.7 \%$ & $40 \%$ \\
\hline
\end{tabular}

AVHL: anterior ver

\section{DISCUSSION}

Percutaneous vertebroplasty was first performed by Galibert and Deromond in France in $1987^{(4)}$.

Percutaneous vertebroplasty is most commonly applied to osteoporotic vertebral fractures ${ }^{(14,15)}$. In osteoporosis, due to low bone mass and deterioration of the microstructure of bone tissue, deformities occur in the vertebra because of trauma. As a result, obvious physical and functional disorders, such as limitation of movement and pain occur ${ }^{(16)}$. This condition, especially seen in old ages, leads to severe low back pain and limitation of movement. Conservative methods such as analgesic therapy for pain, and corset and bed rest to maintain vertebral height are generally not successful. However, the stabilization surgery performed for the osteoporotic compression fracture increases the length of hospital stay, mortality, and morbidity ${ }^{(17,18)}$.

Vertebroplasty, which was developed as an alternative to stabilization surgery, is a less invasive procedure compared to stabilization and is preferred because it reduces both the operative time and reduces the risk of perioperative complications, as the symptoms disappear quickly and the patients are introduced to their social life early ${ }^{(19,20)}$. The postop- 
erative results of vertebroplasty are fairly pleasing. In a case series of 100 patients with osteoporotic vertebral fractures by McGraw et al., $97 \%$ of the patients reported that pain complaints decreased significantly in the first 24 hours and this state of well-being continued for an average follow-up period of 21 months ${ }^{(2)}$. In another study performed by Perez-Higueraz et al., the VAS score, which was 9.1 before the operation, was reported as 2.1 , and 2.2 points at average 72 nd-hour and 2 at the end of fifth-year after the operation ${ }^{(21)}$.

During vertebroplasty, complications may occur, albeit rarely. The most feared complication is systemic embolization through paraspinous veins caused by polymethylmethacrylate during the procedure ${ }^{(22,23)}$. The most common complication during vertebroplasty procedure is leakage of polymethylmethacrylate into the spinal canal or neural foramen. In the series performed by McKiernan et al., this rate was determined as $15 \%$ (13). Therefore, to ensure adequate strength resistance and pain control and to avoid complications, the amount of cement used during vertebroplasty procedures must be at an optimum level. In the literature, several studies are reporting that 3-5 $\mathrm{ml}$ of cementum injection is sufficient for the lumbar vertebra region ${ }^{(9-12)}$. However, the dose-dependent response between the cement volume applied and the strength resistance and hardness is not fully known ${ }^{(8)}$.

In our 60-case series operated, it was observed that the vertebral heights were preserved in both groups during the 1 st-year controls of patients who had received $5 \mathrm{ml}$ or $3 \mathrm{ml}$ polymethylmethacrylate injection. However, in 3 patients who received $5 \mathrm{ml}$ polymethylmethacrylate, it was found that cement escaped to the disc space, anterior part of the vertebral corpus, and towards the spinal canal. For all that, the preoperative mean VAS scores in both groups significantly decreased on postoperative 1st day after the procedure. In addition, no significant change in AHVL height was observed in either group after 1 year of follow-up.

Our results show that $3 \mathrm{ml}$ polymethylmethacrylate injection during percutaneous vertebroplasty procedure provides adequate pain control and stabilization in patients with lumbar osteoporotic vertebral fractures. Therefore, we think that lesser amount $(3 \mathrm{ml})$ of polymethylmethacrylate is sufficient to avoid unnecessary complications in this patient group.

Ethics Committee Approval: Tekirdağ Namık Kemal University Clinical Research Ethics Committee approval was received (26/2/2019; 2019.229.12.04).

Conflict of Interest: No conflict of interest was declared by the authors.

Funding: No funding was used for this study.

Informed Consent: Informed consent was taken from all the participants.

\section{REFERENCES}

1. Langner S, Henker C. Vertebroplasty and kyphoplasty: A critical statement. Radiologe. 2020;60(2):138-43. https://doi.org/10.1007/s00117-020-00651-z

2. McGraw JK, Lippert JA, Minkus KD, et al. Prospective evaluation of pain relief in 100 patients undergoing percutaneous vertebroplasty: results and follow-up. J Vasc Interv Radiol. 2002;13:883-6. https://doi.org/10.1016/S1051-0443(07)61770-9

3. Amar AP, Larsen DW, Esnaashari N, et al. Percutaneous transpedicular polymethylmethacrylate vertebroplasty for the treatment of spinal compression fractures. Neurosurgery. 2001; 49:1105-14; discussion 1114-5. PMID: 11846904. https://doi.org/10.1227/00006123-200111000-00017

4. Galibert $P$, Deramond $H$, Rosat $P$, et al. Preliminary note on the treatment of vertebral angioma by percutaneous acrylic vertebroplasty. Neurochirurgie. 1987; 33:166-8. PMID: 3600949

5. Tang J, Guo WC, Hu JF, et al. Unilateral and Bilateral Percutaneous Kyphoplasty for Thoracolumbar Osteoporotic Compression Fractures. J Coll Physicians Surg Pak. 2019;29(10):946-50. https://doi.org/10.29271/jcpsp.2019.10.946

6. Liebschner MA, Rosenberg WS, Keaveny TM. Effects of bone cement volume and distribution on vertebral stiffness after vertebroplasty. Spine (Phila Pa 1976). 2001;26(14):1547-54. https://doi.org/10.1097/00007632-200107150-00009

7. Deng XQ, Wu YS, Wang HM. Application of contralateral supplementary puncture in unilateral percutaneous vertebroplasty for poor bone cement dispersion. Zhongguo Gu Shang. 2018;31:1168-71.

https://doi.org/10.3969/j.issn.1003-0034.2018.12.019

8. Sun HB, Hai Y. In Reply to "Does Optimal Volume Fraction in Percutaneous Vertebroplasty Prevent Cement Leakage?". World Neurosurg. 2018;116:491.

https://doi.org/10.1016/j.wneu.2018.05.076

9. Kwon HM, Lee SP, Baek JW, Kim SH. Appropriate Cement Volume in Vertebroplasty: A Multivariate Analysis with Short-Term Follow-Up. Korean J Neurotrauma. 2016;12(2):128-34. https://doi.org/10.13004/kjnt.2016.12.2.128

10. Kaufmann TJ, Trout AT, Kallmes DF. The effects of cement volume on clinical outcomes of percutaneous vertebroplasty. AJNR Am J Neuroradiol. 2006;27:1933-7. PMID: 17032870

11. Gstottner M, Angerer A, Rosiek R, Bach CM. Quantitative volumetry of cement leakage in viscosity-controlled vertebroplasty. J Spinal Disord Tech. 2012;25(5):E150-4. https://doi.org/10.1097/BSD.0b013e31823f62b1

12. Sun HB, Jing XS, Liu YZ, Qi M, Wang XK, Hai Y. The optimal volume fraction in percutaneous vertebroplasty evaluated by pain relief, cement dispersion, and cement leakage: a prospective cohort study of 130 patients with painful osteoporotic vertebral compression fracture in the thoracolumbar vertebra. World Neurosurg. 2018;114:e677-e688. https://doi.org/10.1016/j.wneu.2018.03.050

13. McKiernan F, Faciszewski T, Jensen R. Quality of life following vertebroplasty. J Bone Joint Surg Am. 2004;86:2600-6. 
https://doi.org/10.2106/00004623-200412000-00003

14. Yang EZ, Xu JG, Huang GZ, et al. Percutaneous Vertebroplasty versus Conservative Treatment in Aged Patients with Acute Osteoporotic Vertebral Compression Fractures: A Prospective Randomized Controlled Clinical Study. Spine (Phila Pa 1976). 2016;41(8):653-60. https://doi.org/10.1097/BRS.0000000000001298

15. Wang B, Guo H, Yuan L et al. A prospective randomized controlled study comparing the pain relief in patients with osteoporotic vertebral compression fractures with the use of vertebroplasty or facet blocking. Eur Spine J. 2016;25(11):3486-94. https://doi.org/10.1007/s00586-016-4425-4

16. Silverman SL, Minshall ME, Shen W, et al. The relationship of health-related quality of life to prevalent and incident vertebral fractures in postmenopausal women with osteoporosis: results from the Multiple Outcomes of Raloxifene Evaluation Study. Arthritis Rheum. 2001;44(11):2611-9. https://doi.org/10.1002/1529-0131(200111)44:11<2611::AIDART441>3.0.CO;2-N

17. Wong W. Vertebroplasty/kyphoplasty. J Womens Imaging. 2000;2:117-24.

18. Zhang L, Zhai P. A Comparison of Percutaneous Vertebroplasty versus Conservative Treatment in Terms of Treatment Effect for Osteoporotic Vertebral Compression Fractures: A Meta-Analysis. Surg Innov. 2020;27(1):19-25. https://doi.org/10.1177/1553350619869535

19. Theodorou DJ, Theodorou SJ, Duncan TD, et al. Percutaneous balloon kyphoplasty for the correction of spinal deformity in painful vertebral body compression fractures. Clin Imaging. 2002;26:1-5.

https://doi.org/10.1016/\$0899-7071(01)00350-3

20. Yang $\mathrm{W}$, Song J, Liang $\mathrm{M}$, et al. Functional Outcomes and New Vertebral Fractures in Percutaneous Vertebroplasty and Conservative Treatment of Acute Symptomatic Osteoporotic Vertebral Compression Fractures. World Neurosurg. 2019;131 e346-e352.

https://doi.org/10.1016/j.wneu.2019.07.153

21. Perez-Higueras A, Alvarez L, Rossi RE, et al. Percutaneous vertebroplasty: long-term clinical and radiological outcome. Neuroradiology. 2002;44:950-4

https://doi.org/10.1007/s00234-002-0856-1

22. D'Errico S, Niballi $S$, Bonuccelli D. Fatal cardiac perforation and pulmonary embolism of leaked cement after percutaneous vertebroplasty. J Forensic Leg Med. 2019;63:48-51. https://doi.org/10.1016/j.jflm.2019.03.004

23. Hsieh MK, Kao FC, Chiu PY, et al. Risk factors of neurological deficit and pulmonary cement embolism after percutaneous vertebroplasty. J Orthop Surg Res. 2019;14:406.

https://doi.org/10.1186/s13018-019-1459-4 